\title{
PENGARUH MODEL PEMBELAJARAN AKTIF TIPE CARD SORT DAN MOTIVASI BELAJAR DALAM MATA KULIAH KETERAMPILAN BERSASTRA KE SD-AN MAHASISWA PRODI PGSD
}

\author{
Hidayati Azkiya \\ Universitas Bung Hatta \\ id.azkiya@gmail.com \\ 081374663370
}

Naskah diterima: 20 Januari 2017; direvisi: 1 Februari 2017 ; disetujui: 21 April 2017

\begin{abstract}
This study begins from the problem of low skills learning ability to compose Elementary literature in PGSD departement of Bung Hatta University. It can be seen from the results of students' mid semester test, observation, and interviews with faculty to compose literature Skills in elementary course. This study aims to determine the effect of the application of an active learning model type of card sort to compose skills to elementary school's student in PGSD Department and to know the results of learning skills to compose an Elementary course-students after being taught by active learning model type of card sort. This type of research was a Quasi Experimental study. The populations were all students in PGSD department Academic Year 2015/2016.The Data collection techniques in this study used questionnaires of learning motivation and learning skills tests to compose Elementary literature in PGSD. The Data analysis techniques used in this study were $t$ test and ANOVA. Based on the findings, we concluded that first learning skills to compose elementary literature students who use active learning model type of card sort was higher than in convenetional than students who used conventional learning either seen as a whole or from high and low learning motivation. Second, there was no interaction between the learning motivation to learn the skills of learning to compose Elementary literature of PGSD students. It means that active learning model type of card sort gave good effect on learning skilss to compose Elementary literature of PGSD students.
\end{abstract}

Keywords: active learning, mearning motivational, elementary school learning

\begin{abstract}
ABSTRAK
Penelitian ini berawal dari masalah rendahnya kemampuan pembelajaran keterampilan bersastra ke SD-an mahasiswa Prodi PGSD. Hal ini terlihat pada hasil tes ujian tengah semester mahasiswa, hasil observasi, dan wawancara dengan dosen Mata Kuliah Keterampilan Bersastra ke SD-an. Penelitian ini bertujuan untuk mengetahui pengaruh penerapan model pembelajaran aktif tipe card sort terhadap keterampilan bersastra ke SDan mahasiswa Prodi PGSD dan untuk mengetahui hasil belajar Keterampilan Bersastra ke SD-an mahasiswa setelah diajar dengan model pembelajaran aktif tipe card sort. Jenis penelitian yang digunakan adalah penelitian Quasi Eksperimen. Populasi dalam penelitian ini adalah seluruh mahasiswa Prodi PGSD Tahun Ajaran 2015/2016. Teknik pengumpulan data dalam penelitian ini menggunakan angket motivasi belajar dan tes pembelajaran Keterampilan Bersastra ke SD-an. Teknik analisis data yang digunakan pada penelitian ini,
\end{abstract}


yaitu uji-t dan anava. Berdasarkan temuan penelitian, diperoleh kesimpulan. Pertama, pembelajaran Keterampilan Bersastra ke SD-an mahasiswa yang mengikuti pembelajaran menggunakan model pembelajaran aktif tipe card sort lebih tinggi dari pada mahasiswa yang mengikuti pembelajaran konvensional baik dilihat secara keseluruhan, maupun berdasarkan motivasi belajar tinggi dan rendah. Kedua, tidak terdapat interaksi antara model pembelajaran dengan motivasi belajar terhadap pembelajaran Keterampilan Bersastra ke SD-an mahasiswa. Hal ini berarti model pembelajaran aktif tipe card sort berpengaruh baik terhadap pembelajaran Keterampilan Bersastra ke SD-an mahasiswa.

Kata kunci: model pembelajaran, card sort, motivasi belajar, keterampilan bersastra ke SD-an

\section{PENDAHULUAN}

Pendidikan sebagai satu kesatuan yang sistematik diselenggarakan sebagai proses yang berlangsung sepanjang hayat untuk pembudayaan dan pemberdayaan peserta didik. Karena itu, setiap peserta didik perlu mendapatkan pendidikan yang bermutu melalui pemberian kesempatan untuk meningkatkan pendidikan sepanjang hayat. Menurut Undang-undang Sistem Pendidikan Nasional nomor 20 tahun 2003 (UU SPN No. 20 Tahun 2003), pendidikan nasional berperan mengembangkan kemampuan dan membentuk watak serta peradaban bangsa yang bermartabat dalam rangka mencerdaskan kehidupan bangsa. Peran ini bertujuan untuk mengembangkan potensi peserta didik agar menjadi manusia yang beriman dan bertaqwa kepada Tuhan Yang Maha Esa, berakhlak mulia, sehat, berilmu, cakap, kreatif, mandiri, menjadi warga negara yang demokratis dan bertanggung jawab. Pelaksanaan pendidikan yang mengembangkan kemampuan dan watak serta martabat bangsa seperti yang disebutkan dalam UU SPN nomor 20 tahun 2003 tersebut, harus dilaksanakan secara interaktif, inspiratif, menyenangkan dengan jalan memotivasi peserta didik berpastisipasi aktif, serta memberikan ruang yang cukup bagi prakarsa, kreativitas, dan kemandirian sesuai dengan bakat, minat, dan perkembangan fisik serta psikologis peserta didik (PP Nomor 19 Tahun 2005).

Interaktif, inspiratif, menyenangkan, menantang, kreatif, dan kemandirian dalam proses pembelajaran berkaitan dengan adanya aksi dan reaksi dari peseta didik. Hal ini dapat diwujudkan ketika peserta didik terlibat aktif dalam pembelajaran. Bagi dirinya sendiri melalui keaktivan peserta didik, terlibat dalam proses pembelajaran dan mereka mendapatkan pengetahuan yang berpotensi menjadi pengalaman, kemudian pengalaman yang dimiliki peserta didik tersebut menjadi cikal bakal pembentukan kompetensi. Selain itu, kegiatan pembelajaran menjadi lebih interaktif, jika kegiatan tersebut menjadi kegiatan yang inspiratif dan menyenangkan. Hal itu dapat dicapai melalui proses pembelajaran memotivasi mahasiswa untuk membangun kelas yang parsitipatif berdasarkan prakarsa, kreativitas dan kemandirian mahasiswa sesuai dengan bakat dan perkembangan masing-masing mahasiswa.

Pelaksanaan pembelajaran yang disebutkan pada PP nomor 19 tahun 2005 tersebut, dijelaskan oleh Permendiknas nomor 41 tahun 2007 bahwa pembelajaran dilakukan sesuai dengan standar proses yang mensyaratkan bahwa dalam proses pembelajaran, seorang pendidik harus dapat memperhatikan karakteristik peserta didiknya. Karakteristik peserta didik, bagi Smaldino (2008) terdiri dari dua hal: pertama, karakteristik umum yang terdiri dari usia, gender, kelas, faktor budaya serta sosio ekonomi. Kedua, kopetensi spesifik seperti gaya belajar yang berhubungan dengan kecerdasan majemuk, kekuatan 
konsptual, kebiasaan memproses informasi, motivasi, dan faktor fisiologi.

Proses pembelajaran selama ini belum memenuhi seperti yang disebutkan pada PP nomor 19 tahun 2005 dan Permendiknas nomor 41 tahun 2007. Padahal untuk beberapa sekolah dan lembaga memiliki inprastruktur yang mendukung untuk mewujudkan pelaksaan pembelajaran seperti yang disebutkan pada PP sebelumnya termasuk pada mata kuliah Keterampilan Bersastra. Keterampilan bersastra ke SD-an merupakan mata kuliah yang membahas tentang pengetahuan dan pemahaman tentang genre sastra (prosa, fiksi, dan drama). Adapun tujuan keterampilan bersastra adalah supaya mahasiswa memiliki pengetahuan dan kemampuan dasar mengenai gendre sastra (prosa, fiksi, dan drama) kemudian terampil mendisain pembelajaran sastra ke SD-an dan mengajarkannya kepada murid sekolah dasar.

Berdasarkan tujuan mata kuliah Keterampilan Bersastra ke SD-an tersebut, penulis melakukan observasidi di Prodi PGSD untuk melihat proses pembelajaran Mata Kuliah Keterampilan Bersastra ke SD-an. Dari hasil observasi, ternyata mahasiswa kurang bersemangat untuk belajar, karena proses pembelajaran yang digunakan masih pendekatan tradisional seperti mencatat, mendengar, dan mengerjakan latihan. Melalui metode ceramah, dosen cendrung memanfaatkan buku teks saja. Tidak terdapat model lain dalam pembelajaran Keterampilan Bersastra ke SD-an. Hal ini menyebabkan mahasiswa kurang tertarik untuk belajar, dan proses pembelajaranpun hanya memberi penekanan pada konsep-konsep yang terdapat dalam buku saja.

Selain observasi, peneliti juga melakukan wawancara dengan dosen mata kuliah Keterampilan Bersastra ke SD-an yaitu Ibu Yulia Helti, M.Pd. Beliau memaparkan bahwa dalam mata kuliah Keterampilan Bersastra ke SD-an mahasiswa terkadang kurang paham tentang materi yang disampaikan karena kurangnya penerapan model yang sesuai dengan materi. Selain itu, hanya sebagian mahasiswa saja yang aktif dalam mengikuti pelajaran. Terkadang mahasiswa meribut atau berbicara dengan temannya saat dosen menjelaskan materi pelajaran.

Berdasarkan permasalahan tersebut, dosen sebagai fasilitator pembelajaran, harus berusaha membangun keaktifan dan keberanian mahasiswa untuk mampu memahami sendiri dan mempraktikan pembelajaran Keterampilan Bersastra ke SD-an, menumbuhkan motivasi mahasiswa belajar mandiri (independent learning) sehingga pelajaran Keterampilan Bersastra ke SD-an menjadi hal yang menyenangkan karena mahasiswa memperoleh sendiri pengetahuannya. Motivasi merupakan penggerak perilaku. Untuk itu, motivasi timbul karena adanya keinginan atau kebutuhan-kebutuhan dalam diri seseorang. Seseorang berhasil dalam belajar, karena ingin belajar. Motivasi belajar merupakan faktor psikis yang bersifat non intelektual. Peranannya yang khas ialah dalam hal gairah atau semangat belajar, mahasiswa yang termotivasi kuat akan mempunyai banyak energi untuk melakukan kegiatan belajar. Salah satu model yang bisa digunakan dosen untuk memotivasi mahasiswa dalam proses pembelajaran Keterampilan Bersastra ke SD-an adalah dengan menggunakan model pembelajaran aktif tipe card sort.

Selanjutnya, faktor psikologis yang mempengaruhi hasil belajar mahasiswa ialah sikap, motivasi, dan minat. Sikap merupakan kesiapan seseorang untuk bertindak secara tertentu terhadap hal-hal tertentu. Sikap mahasiswa yang positif terhadap pembelajaran Keterampilan Bersastra ke SD-an di perdosenan tinggi merupakan langkah awal yang baik dalam proses belajar mengajar di kelas. Sedangkan sikap yang pasif, rendah diri dan kurang percaya diri, dapat merupakan faktor yang menghambat mahasiswa dalam menampilkan prestasi belajarnya. Kurangnya sikap positif mahasiswa terhadap pembelajaran Keterampilan 
Bersastra ke SD-an berakibat hasil belajar Keterampilan Bersastra ke SD-an tidak maksimal.

Selanjutnya, faktor psikologis yang mempengaruhi yaitu minat. Minat merupakan dorongan yang berasal dalam diri seseorang untuk melakukan sesuatu. Dalam proses pembelajaran, mahasiswa cenderung kurang berminat dalam belajar Keterampilan Bersastra ke SD-an. Tanpa adanya minat dalam diri mahasiswa, maka mahasiswa tidak akan mampu bersungguhsungguh mengikuti pembelajaran, sehingga berdampak buruk terhadap hasil belajar yang diperoleh mahasiswa. Apabila mahasiswa yang memiliki minat yang tinggi, maka hasil belajar yang dihasilkan akan lebih baik dibandingkan mahasiswa yang memiliki minat yang rendah. Selain itu, dengan adanya minat, tentu mahasiswa akan memperoleh pengetahuan dan wawasan yang luas sehingga membantu keberhasilan dalam proses pembelajaran Keterampilan Bersastra ke SD-an.

Faktor kompetensi yang mempengaruhi hasil belajar mahasiswa ialah intelegensi dan keterampilan. Prestasi belajar yang ditampilkan mahasiswa mempunyai kaitan yang erat dengan tingkat kecerdasan yang dimiliki mahasiswa. Intelegensi adalah kecerdasan yang dimiliki oleh seseorang. Taraf intelegensi ini sangat mempengaruhi hasil belajar mahasiswa. Mahasiswa yang memiliki taraf intelegensi tinggi mempunyai peluang lebih besar untuk mencapai hasil belajar yang lebih tinggi. Sebaliknya, mahasiswa yang memiliki taraf intelegensi yang rendah diperkirakan juga akan memiliki hasil belajar yang rendah. Namun, bukanlah suatu yang tidak mungkin jika mahasiswa dengan taraf intelegensi rendah memiliki hasil belajar yang tinggi, juga sebaliknya.

Faktor pembelajaran yang ikut mempengaruhi hasil belajar Keterampilan Bersastra ke SD-an lainnya ialah metode pembelajaran dan materi pembelajaran. Dalam kegiatan pembelajaran diperlukan metode-metode yang dapat membantu meningkatkan keinginan mahasiswa untuk belajar. Pemilihan model pembelajaran harus sesuai dengan materi yang dipelajari, sehingga mahasiswa semangat dalam mengikuti pembelajaran. Selama ini, pelaksanaan model pembelajaran Keterampilan Bersastra ke SD-an cenderung disajikan ke dalam metode ceramah, tanya jawab dan berdiskusi. Dosen senantiasa kurang memberdayakan potensi kreatif mahasiswa dalam pemakaian model pembelajaran, dan masih kurang kreatif dalam mengelola pembelajaran Keterampilan Bersastra ke SD-an di kelas. Dosen Keterampilan Bersastra ke SD-an perlu menguasai dan mampu menerapkan berbagai model, pendekatan, dan metode dalam proses belajar mengajar di kelas, agar proses belajar mengajar tersebut tidak menoton dan membosankan. Dalam pembelajaran, khususnya pembelajaran Keterampilan Bersastra ke SD-an, peran dosen sangat besar dan dosen benar-benar ditantang untuk menghadirkan model yang memfasilitasi mahasiswa untuk belajar sendiri untuk menunjang tercapainya tujuan pembelajaran Keterampilan Bersastra ke SD-an. Dalam pembelajaran, khususnya pembelajaran Keterampilan Bersastra ke SD-an, buku sumber menjadi satu-satunya sumber belajar bagi mahasiswa dan tidak ada tambaham materi yang sesuai dengan materi pembelajaran yang dipelajari.

Berdasarkan masalah yang telah dikemukakan, model pembelajaran aktif tipe card sort merupakan salah satu model yang dipandang efektif dan menyenangkan. Adapun kelebihan model pembelajaran aktif tipe card sort adalah mahasiswa lebih mudah menangkap materi, mahasiswa lebih antusias, dan sosialisasi antar mahasiswa lebih terbangaun. Serta kelemahannya, mahasiswa memerlukan perhatian lebih dan banyak menyita waktu. Meskipun demikian, dengan menggunakan model ini diharapkan mahasiswa akan lebih mudah menjelaskan ide-ide dan gagasan maupun pengalamannya secara beraturan dengan menggunakan kartu yang 
berwarna-warni dan bergambar, sehingga akan memudahkan mahasiswa mencurahkan ide secara kreatif dan berdasarkan pola pemikiran masing-masing.

Berdasarkan uraian tersebut, penerapan model card sort diharapkan akan dapat mempengaruhi hasil belajar Keterampilan Bersastra ke SD-an mahasiswa. Selain itu, motivasi belajar siswa juga diharapkan dapat mempengaruhi hasil belajar Keterampilan Bersastra ke SD-an mahasiswa.

Adapun teori yang digunakan adalah tentang model pembelajaran menurut Prawiradilaga (2009:33) diartikan sebagai tampilan grafis, prosedur kerja yang teratur atau sistematis, serta mengandung pemikiran bersifat uraian dan sasaran yang dibangun atas dasar teori belajar, pembelajaran, psikologi, komunikasi, dan sistem. Menurut Joyce, Weil, dan Calhoul (2009:9), model pembelajaran merupakan pola umum perilaku pembelajaran untuk membantu peserta didik memperoleh informasi, ide, kemampuan, nilai, cara berpikir, dan sarana mengekspresikan diri. Pengertian model yang dikemukakan Prawiradilaga (2009:33) diperkuat oleh Brown (2011:7) bahwa prosedur kerja yang berupa tampilan grafis tersebut adalah refleksi apa yang terjadi yang mengikuti prosur kerja yang teratur dan sistematis yang dilandasi teori belajar, pembelajaran, psikologi, komunikasi dan system. Jadi, dapat disimpulkan bahwa model pembelajaran merupakan gambaran realitas lingkungan belajar yang memilki tampilan grafis dan sitematis yang dilandasi teori belajar, pembelajaran, psikologi, komunikasi dan sistem untuk membantu peseta didik memperoleh informasi, ide, kemampuan, nilai, cara berpikir, dan sarana mengekspresikan diri.

Pembelajaram aktif (aktif learning) adalah proses belajar dimana peserta didik mendapat kesempatan untuk lebih banyak melakukan aktivitas belajar, berupa hubungan interaktif dengan materi pelajaran sehingga terdorong untuk menyimpulkan pemahaman dari pada hanya sekedar pembelajaran yang diberikan. Mayer dan Jones (1993) mengemukakan bahwa pembelajaran aktif terjadi aktivitas berbicara dan mendengar, menulis, membaca, dan refleksi yang mengiring ke arah pemaknaan mengenai isi pelajaran, ide-ide, dan berbagai hal yang berkaitan dengan satu topik yang sedang dipelajari. Dalam pembelajaran aktif, dosen lebih berperan sebagai fasilitator bukan hanya sekedar transfer of knowledge.

Di samping itu, prinsip dari pembelajaran aktif adalah mahasiswa harus gesit, bersemangat, menyenangkan, dan penuh gairah. Mereka harus memfungsikan otak, mengakaji sebuah gagasan, mencari solusi untuk memecahkan masalah dan menerapkan apa yang mereka pelajari. Sehingga keaktivan mahasiswa dalam pembelajaran lebih dominan.

Dapat disimpulkan bahwa pembelajaran aktif merupakan proses belajar dimana peserta didik mendapat kesempatan untuk lebih banyak melakukan aktivitas belajar, berupa hubungan interaktif dengan materi pelajaran sehingga terdorong untuk menyimpulkan pemahaman dari pada hanya sekedar pembelajaran yang diberikan. Dengan kata lain, prinsip dari pembelajaran aktif adalah mahasiswa harus gesit, bersemangat, menyenangkan, dan penuh gairah. Mereka harus memfungsikan otak, mengakaji sebuah gagasan, mencari solusi untuk memecahkan masalah dan menerapkan apa yang mereka pelajari. Sehingga keaktivan mahasiswa dalam pembelajaran lebih dominan.

Adapun model pembelajaran tipe aktif card sort merupakan aktivitas kerjasama yang bisa digunakan untuk mengajarkan konsep, karakteristik klasifikasi, fakta tentang benda, atau menilai informasi. Gerak fisik di dalamnya dapat membantu mahasiswa menghilangkan kejenuhan Silberman (dalam Muttaqin, 1996).

Selain itu, dalam model pembelajaran aktif tipe card sort yang diungkapkan oleh Silberman bahwa penggunaan kartu yang 
berdimensi visual dalam pembelajaran dapat meningkatkan ingatan dari 14-38\%. Di samping itu, model pembelajaran aktif tipe card sort yang berdimensi visual juga melibatkan dua belah otak yakni otak kiri dan kanan, sehingga mahasiswa merasa senang dengan model pembelajaran.

Adapun prosedur-prosedur model pembelajaran aktif tipe card sort adalah sebagai berikut: (1) menjelaskan materi pelajaran dan menjelaskan model pembelajaran yang akan diterapkan secara singkat. (2) Memberi setiap mahasiswa kartu yang berisi kategori yang cocok dengan satu kartu atau beberapa kartu. (3) Memerintahkan kepada mahasiswa untuk berkeliling ruangan dan mencari mahasiswa lain yang kartunya cocok dengan katergori yang sama. (4) Kemudian perintahkan kepada mahasiswa yang kategorinya sama untuk berdiskusi memberikan kesimpulan. (5) Ketika mahasiswa berdiskusi, kemukakan poin-poin pengajaran yang menurut anda penting. (6) Perintahkan kepada siwa untuk mempresentasikan hasil kesimpulan dari diskusi tipa-tiap kategori yang terkumpul.

Istilah motivasi berasal dari kata motif, yang mempunyai makna sebagai kekuatan yang terdapat pada diri untuk berbuat atau melakukan sesuatu. Motivasi merupakan gambaran berbagai proses yang dapat membangun dan memulai perilaku, memberikan arah dan tujuan pada perilaku, memungkinkan perilaku untuk terus bertahan dan memberikan arahan pilihan yang harus dilakukan oleh sseorang.

Harold Koontz, dkk (1980: 632) mengemukakan bahwa motivasi, "is anner state that energizes, activates or moves (hence motivation) and that directs or channels behavior toward goals" adalah suatu keadaan dari dalam yang memberi kekuatan, yang menggiatkan atau yang menggerakkan sehingga disebut 'penggerakan' atau 'motivasi' yang mengarahkan atau menyalurkan perilaku ke arah tujuan- tujuan. Sedangkan Guralnik (1979: 314), menjelaskan bahwa motivasi adalah motive an inner drive, impulse, etc.,that causes one to act. Motivasi sebagai suatu perangsang dari dalam, suatu gerak hati dan sebagainya yang menyebabkan seseorang melakukan sesuatu.

Berdasarkan uraian tersebut, maka dapat disimpulkan bahwa motivasi adalah dorongan dalam diri seseorang untuk melakukan sesuatu hal sehingga terwujudnya tujuan yang diinginkan. Dalam kegiatan belajar, motivasi dapat dikatakan sebagai keseluruhan daya penggerak dalam diri siswa yang menimbulkan, menjamin kelangsungan, dan memberikan arah kegiatan belajar. Sehingga diharapkan tujuan yang ada dapat tercapai. Dalam kegiatan belajar, motivasi sangat diperlukan oleh siswa. Sebab siswa yang tidak mempunyai motivasi dalam belajar tidak akan mungkin melakukan aktivitas belajar.

Memberikan motivasi kepada siswa berarti menggerakkan siswa untuk melakukan sesuatu atau ingin melakukan sesuatu. Untuk itu, motivasi belajar memegang peranan penting dalam memberikan gairah, semangat, dan rasa tenang dalam belajar sehingga yang mempunyai motivasi yang tinggi mempunyai energi yang banyak untuk melaksanakan kegiatan belajar. Sardiman (2006:83) secara umum mengemukakan ciri-ciri umum motivasi sebagai berikut. Pertama, tekun menghadapi tugas (dapat bekerja terus-menerus dalam waktu yang lama, tidak pernah berhenti sebelum selesai. Kedua, ulet menghadapi kesulitan (tidak lekas putus asa). Tidak memerlukan dorongan dari luar untuk berprestasi sebaik mungkin (tidak cepat puas dengan prestasi yang telah dicapainya). Ketiga, menunjukan minat terhadap bermacammacam masalah untuk orang dewasa. Keempat, lebih senang bekerja mandiri.Kelima, cepat bosan pada tugastugas yang rutin. Keenam, dapat mempertahankan pendapatnya. Ketujuh, tidak mudah melepaskan hal yang diyakini itu. Kedelapan, senang mencari dan memecahkan masalah soal-soal. 
Uno (2012:31) mengemukakan ciriciri motivasi dalam belajar diantaranya: (1) adanya hasrat dan keinginan berhasil; (2) adanya dorongan dan kebutuhan dalam belajar; (3) adanya harapan dan cita-cita masa depan; (4) adanya penghargaan dalam belajar; (5) adanya kegiataan yang menarik dalam belajar; (6) adanya lingkungan belajar yang kondusif sehingga memungkinkan seseorang siswa dapat belajar dengan baik.

Sastra (Sanskerta: shastra) merupakan kata serapan dari bahasa Sanskerta 'Sastra', yang berarti teks yang mengandung instruksi atau pedoman, dari kata dasar 'Sas' yang berarti instruksi atau ajaran dan 'Tra' yang berarti alat atau sarana. Dalam bahasa Indonesia kata ini biasa digunakan untuk merujuk kepada "kesusastraan" atau sebuah jenis tulisan yang memiliki arti atau keindahan tertentu.

Di sekolah dasar, pembelajaran sastra dimaksudkan untuk meningkatkan kemampuan siswa mengapresiasi karya sastra. Kegiatan mengapresiasi sastra berkaitan dengan latihan mempertajam perasaan, penalaran, daya khayal, serta kepekaan terhadap masyarakat, budaya dan lingkungan hidup. Pengembangan kemampuan bersastra di sekolah dasar dilakukan dalam berbagai jenis dan bentuk melalui kegiatan mendengarkan, berbicara, membaca, dan menulis. Adapun pemilihan bahan ajar tersebut dapat dicari pada sumbersumber yang relevan (Depdiknas, 2003 ).

Pembelajaran sastra di SD adalah Pembelajaran sastra anak. Sastra anak adalah karya sastra yang secara khusus dapat dipahami oleh anak-anak dan berisi tentang dunia yang akrab dengan anakanak, yaitu anak yang berusia antara 6-13 tahun. Sifat sastra anak adalah imajinasi semata, bukan berdasarkan pada fakta. Unsur imajinasi ini sangat menonjol dalam sastra anak. Hakikat sastra anak harus sesuai dengan dunia dan alam kehidupan anak-anak yang khas milik mereka dan bukan milik orang dewasa. Sastra anak bertumpu dan bermula pada penyajian nilai dan imbauan tertentu yang dianggap sebagai pedoman tingkah laku dalam kehidupan.

Sastra anak berfungsi sebagai media pendidikan dan hiburan, membentuk kepribadian anak, serta menuntun kecerdasan emosi anak. Pendidikan dalam sastra anak memuat amanat tentang moral, pembentukan kepribadian anak, mengembangkan imajinasi dan kreativitas, serta memberi pengetahuan keterampilan praktis bagi anak. Fungsi hiburan dalam sastra anak dapat membuat anak merasa bahagia atau senang membaca, senang dan gembira mendengarkan cerita ketika dibacakan atau dideklamasikan, dan mendapatkan kenikmatan atau kepuasan batin sehingga menuntun kecerdasan emosinya.

\section{METODE PENELITIAN}

Jenis penelitian ini adalah penelitian kuantitatif. Prosedur dalam pengolahan data penelitian yang dilakukan dalam penelitian ini dituntut menggunakan angkaangka. Angka dalam penelitian ini adalah skor dan nilai angket motivasi belajar mahasiswa serta skor dan nilai dari hasil belajar Keterampilan Bersastra ke SD-an Mahasiswa Prodi PGSD.

Populasi penelitian ini adalah 150 orang mahasiswa yang adalah seluruh mahasiswa Prodi PGSD FKIP Universitas Bung Hatta Padang tahun ajaran 2015/2016. Sampel penelitian ini adalah kelas II. B sebagai kelas eksperimen dan kelas II. A sebagai kelas kontrol.

Rancangan yang digunakan dalam peneliatian ini adalah randomizet posttest only control group design. Jenis penelitian ini adalah kuasi eksperimen untuk menerapkan suatu model pembelajaran dalam mata kuliah Keterampilan Bersastra ke SD-an.

Mahasiswa dalam penelitian kuasi eksperimen terdiri dari dua kelas, yaitu satu kelas eksperimen dan satu kelas kontrol. Kelas eksperimen diberi perlakuan menggunakan model pembelajaran aktif tipe card sort, sedangkan kelas kontrol 
diberi perlakuan menggunakan model pembelajaran konvensional. Penelitian ini berupaya menemukan perbedaan hasil belajar berupa hasil belajar Keterampilan Bersastra ke SD-an yang dicapai mahasiswa yang diajar menggunakan model pembelajaran aktif tipe card sort dan siswa yang diajar menggunakan model pembelajaran konvensional.

Data yang akan dikumpulkan dalam penelitian ini adalah data motivasi belajar siswa dan data hasil belajar Keterampilan Bersastra ke SD-an. Data motivasi belajar siswa diperoleh dari tes angket motivasi belajar yang telah diuji validitas dan reliabilitasnya. Angket diberikan kepada siswa sebelum pelaksanaan kegiatan pembelajaran. Sedangkan instrumen hasil belajar Keterampilan Bersastra ke SD-an siswa yang digunakan dalam penelitian ini adalah soal tes yang berbentuk esai.

Data yang diperoleh dalam penelitian ini adalah data kuantitatif, yang berupa nilai angket motivasi dan tes esai. Untuk uji hipotesis 1, 2 dan 3 digunakan uji perbedaan atau uji-t, sedangkan pengujian hipotesis ke 4 dilakukan dengan menggunakan anava. Sebagai syarat melakukan uji-t adalah bahwa subjek harus berdistribusi normal, sehingga perlu dilakukan uji normalitas.

\section{HASIL DAN PEMBAHASAN}

Pada bagian ini akan diuraikan empat pokok kajian yang dikaitkan dengan teori yang relevan sebagai berikut. Pertama, hasil Keterampilan Bersastra ke SD-an mahasiswa kelas eksperimen dan kelas kontrol. Kedua, hasil Keterampilan Bersastra ke SD-an mahasiswa yang memiliki motivasi belajar tinggi. Ketiga, hasil Keterampilan Bersastra ke SD-an mahasiswa yang memiliki motivasi belajar rendah. Keempat, interaksi antara model pembelajaran aktif tipe card sort dengan motivasi belajar terhadap hasil Keterampilan Bersastra ke SD-an.

\section{Hasil Keterampilan Bersastra ke SD-an Mahasiswa Kelas Ekspe- rimen dan Kelas Kontrol}

Pengujian hipotesis pertama menunjukkan bahwa Keterampilan Bersastra ke SD-an mahasiswa melalui model pembelajaran aktif tipe card sort lebih tinggi dari pada Keterampilan Bersastra ke SD-an mahasiswa yang menggunakan pembelajaran konvensional.

Hal ini terjadi karena mahasiswa yang belajar dengan model pembelajaran aktif tipe card sort terlibat secara aktif dan menyenangkan. Mahasiswa akan lebih mudah menjelaskan ide-ide dan gagasan maupun pengalamannya secara beraturan. Jadi, dalam berpikir mahasiswa sebenarnya sedang melakukan dan mengasah kemampuan mereka. Seperti yang disampaikan Mayer dan Jones (1993), bahwa pembelajaran aktif terjadi aktivitas berbicara dan mendengar, menulis, membaca, dan refleksi yang mengiring ke arah pemaknaan mengenai isi pelajaran, ide-ide, dan berbagai hal yang berkaitan dengan satu topik yang sedang dipelajari.

Pada tahap dosen mengorganisasikan mahasiswa untuk belajar, mahasiswa mendiskusikan jawaban dengan teman sekelompoknya agar semua pertanyaan terselesaikan dan mendapatkan solusi yang dianggap paling tepat dalam menyelesaikan pertanyaan yang diberikan. Melalui diskusi akan memperdalam pemahaman mahasiswa terhadap pertanyaan yang dihadapinya, dan dengan berdiskusi mahasiswa dapat menemukan jawaban dengan tepat dan sesuai dengan menimbang-nimbang jawaban mana yang paling tepat untuk pertanyaan yang diberikan. Pendapat Baroody (Elida, 2012: 182) menguraikan beberapa kelebihan dari diskusi kelas, salah satu diantaranya yaitu membantu mahasiswa menganalisis dan menyelesaikan permasalahan secara bijaksana. Pendapat Frank dan Jarvis (2009) yang menyatakan bahwa berdiskusi dan menulis masalah serta gagasan dapat memberi pengaruh positif pada ingatan dan pengembangan konsep. 
Pada tahap penyelidikan, mahasiswa melakukan diskusi untuk menyelesaikan pertanyaan yang diberikan. Mahasiswa saling beradu pendapat untuk mendapatkan jawaban yang paling tepat. Dalam model pembelajaran aktif tipe card sort ini menimbulkan kepuasaan intelektual dalam diri mahasiswa, meningkatkan potensi intelektual, dan melatih bagaimana mahasiswa melakukan penelusuran. Hal ini relevan dengan pendapat Bonwell (dalam Ramadhani, 2009), bahwa mahasiswa harus gesit, bersemangat, menyenangkan, dan penuh gairah. Mereka harus memfungsikan otak, mengakaji sebuah gagasan, mencari solusi untuk memecahkan masalah dan menerapkan apa yang mereka pelajari. Sehingga keaktivan mahasiswa dalam pembelajaran lebih dominan.

Pada model pembelajaran aktif tipe card sort ini. mahasiswa melakukan aktivitas kerjasama yang bisa digunakan untuk mengajarkan konsep, karakteristik klasifikasi, fakta tentang benda, atau menilai informasi dengan menggunakan kartu. Gerak fisik di dalamnya dapat membantu mahasiswa menghilangkan kejenuhan. Dalam pembelajaran aktif tipe cart sort juga dapat meningkatkan aktivitas mahasiswa, mengembangkan minat mahasiswa terhadap pembelajaran sehingga dalam proses pembelajaran mahasiswa mendapatkan hasil yang maksimal. Mahasiswa juga bebas mengkomunikasikan pendapatnya secara klasikal karena dalam pelaksanaan tahapan model pembelajaran aktif tipe card sort beberapa kelompok mahasiswa diberi kesempatan untuk mempresentasikan hasil temuan kelompoknya, kemudian mahasiswa yang lain diminta untuk memberi tanggapan baik berupa pendapat atau berupa pertanyaan, dengan demikian mahasiswa merasa lebih bebas dalam mengkomunikasikan ide-ide yang ada.

Proses pembelajaran yang berlangsung selama penelitian, mahasiswa sudah terbiasa untuk berpikir dalam menyelesaikan pertanyaan yang diberikan, yaitu dengan memahami permasalahan terlebih dahulu. Kemudian dilanjutkan dengan merencanakan jawaban dari masalah yang tepat, melaksanakan strategi yang dipilih, serta memeriksa kebenaran dari hasil yang didapatkan. Kondisi ini membuat Keterampilan Bersastra ke SD-an mahasiswa menjadi lebih baik.

Pada pembelajaran konvensional, mahasiswa terbiasa menunggu penjelasan dari dosen. Secara umum, mahasiswa tidak punya inisiatif melakukan diskusi yang berhubungan dengan materi pembelajaran yang sedang berlangsung.

Berdasarkan penjelasan tersebut, dapat dikatakan bahwa hal-hal tersebutlah yang merupakan penyebab terjadinya Keterampilan Bersastra ke SD-an mahasiswa melalui model pembelajaran aktif tipe card sort lebih tinggi dari pada Keterampilan Bersastra ke SD-an mahasiswa yang menggunakan pembelajaran konvensional.

\section{Hasil Keterampilan Bersastra ke SD-an Mahasiswa yang Memiliki Motivasi Belajar Tinggi}

Pengujian hipotesis kedua menunjukkan bahwa Keterampilan Bersastra ke SD-an mahasiswa yang mempunyai motivasi belajar tinggi yang diajar menggunakan model pembelajaran aktif tipe card sort lebih tinggi dari pada mahasiswa yang mempunya motivasi belajar tinggi yang diajar menggunakan model pembelajaran konvensional.

Menurut Charles (Adi W. Gunawan: 2004), teori kecerdasan umum mengatakan bahwa manusia mempunyai sebuah kemampuan mental umum yang mendasari serta kemampuannya untuk menangani kerumitan kognitif. Bagi mahasiswa yang tidak pencemas atau memiliki motivasi belajar tinggi, belajarnya akan lebih tinggi dalam situasi pembelajaran yang fleksibel. Hal ini berarti, mahasiswa yang memiliki motivasi belajar tinggi lebih mudah belajar secara mandiri, dosen tidak banyak terlibat dalam pembelajaran, situasinya lebih fleksibel karena mereka yakin akan keberhasilan mereka dalam belajar. Hal ini 
akan berdampak pada kemampuan mahasiswa untuk mengembangkan Keterampilan Bersastra ke SD-an.

Lingkungan yang kaya akan stimulus dan tantangan dapat membantu koneksi sel otak. Mahasiswa telah memiliki kecerdasan untuk menangani masalah sehingga mahasiswa dapat memecahkan masalah yang diberikan dosen berupa soal Keterampilan Bersastra ke SD-an. Kecerdasan ini bisa digunakan mahasiswa dalam menganalisis, mengaplikasikan, bertanya, atau memecahkan persoalan Keterampilan Bersastra ke SD-an dengan menghubungkannya dengan masalah kehidupan sehari-hari. Selain itu, motivasi belajar sebagai seperangkat faktor penentu dan bagaimana seseorang berperilaku, bagaimana cara berpikirnya, serta bagaimana reaksi-reaksi emosionalnya dalam mengatasi suatu masalah.

Pembelajaran aktif tipe card sort merupakan suatu model yang memberikan masalah dunia nyata atau masalah kehidupan sehari-hari yang berkaitan dengan Keterampilan Bersastra ke SD-an. Jika mahasiswa dihadapkan pada masalah, maka motivasi belajar yang dimilikinya akan mempengaruhi reaksinya terhadap situasi tersebut. Mahasiswa yang memiliki motivasi belajar tinggi ini akan memilih pola adaptasi tetentu dalam menghadapi masalah dan mengembangkan usaha untuk menyelesaikan masalah tersebut. Hal inilah yang tidak terjadi pada kelas konvensional. Motivasi belajar akan terlihat dari tindakan yang dilakukan seseorang melalui proses tertentu bukan terbentuk dengan sendirinya. Sedangkan pada kelas konvensional, dosen sangat berpengaruh dalam pengambilan keputusan dan mempengaruhi tindakan yang akan dilakukan mahasiswanya, karena konsep diberikan oleh dosen, bukan mahasiswa yang menemukan sendiri seperti pada kelas eksperimen yang menggunakan model pembelajaran aktif tipe card sort.

\section{Hasil Keterampilan Bersastra ke SD-an Mahasiswa yang Memiliki Motivasi Belajar Rendah \\ Pengujian hipotesis}

menunjukkan bahwa Keterampilan Bersastra ke SD-an mahasiswa yang memiliki motivasi belajar rendah yang diajar menggunakan model pembelajaran aktif tipe card sort lebih tinggi dari pada mahasiswa yang menggunakan pembelajaran konvensional.

Menurut Silberman bahwa model pembelajaran tipe aktif card sort merupakan aktivitas kerjasama yang bisa digunakan untuk mengajarkan konsep, karakteristik klasifikasi, fakta tentang benda, atau menilai informasi. Gerak fisik di dalamnya dapat membantu mahasiswa menghilangkan kejenuhan.

Adapun prosedur-prosedur model pembelajaran aktif tipe card sort adalah sebagai berikut: dosen menjelaskan materi pelajaran dan menjelaskan model pembelajaran yang akan diterapkan secara singkat. Memberi setiap mahasiswa kartu yang berisi kategori yang cocok dengan satu kartu atau beberapa kartu. Memerintahkan kepada mahasiswa untuk berkeliling ruangan dan mencari mahasiswa lain yang kartunya cocok dengan katergori yang sama. Kemudian, perintahkan kepada mahasiswa yang kategorinya sama untuk berdiskusi memberikan kesimpulan. Ketika mahasiswa berdiskusi, kemukakan poinpoin pengajaran yang menurut anda penting. Perintahkan kepada mahasiswa untuk mempresentasikan hasil kesimpulan dari diskusi tipa-tiap kategori yang terkumpul.

Melalui proses diskusi ini dapat menumbuh kembangkan rasa ingin tahu mahasiswa, sehingga mereka akan berusaha mencari jalan permasalahan penyelesaian dengan caranya sendiri. Adanya kemampuan menyelesaikan suatu permasalahan akan menimbulkan motivasi belajar yang lebih tinggi dalam diri mahasiswa. Hal ini sejalan dengan apa yang dikemukakan oleh Schunk (1987) 
bahwa mahasiswa dengan motivasi belajar yang rendah mungkin menghindari pelajaran yang banyak tugasnya, khususnya tugas-tugas yang menantang, sedangkan mahasiswa dengan motivasi belajar yang tinggi mempunyai keinginan yang besar untuk mengerjakan tugasnya.

Dalam menciptakan lingkungan belajar sepanjang proses pembelajaran, guru senantiasa memberi kesempatan kepada mahasiswa untuk mengembangkan motivasi dan kemampuan aktualnya. Mahasiswa yang merasa kesulitan mengembangkan kemampuannya bisa bertanya kepada teman lain dalam kelompoknya yang sudah paham lebih dulu. Jika hal ini tidak berhasil, maka dosen memberikan arahan atau pertanyanpertanyaan guna membantu mahasiswa tersebut. Suatu kenyataan yang harus dipahami dosen adalah bahwa akan terdapat banyak ragam mahasiswa baik itu kemampuan, karakter maupun motivasi belajarsiswa, sehingga dosen dituntut untuk aktif berkeliling dan mengidentifikasi mahasiswa atau kelompok mahasiswa yang memerlukan bantuan.

Bagi para mahasiswa di kelompok kontrol kurang dapat mengembangkan interpretasinya dan kurang mampu memberikan argumen-argumen yang lebih kompleks, serta belum bisa membuat kesimpulan dari hasil kerjanya.

\section{Interaksi antara Model Pembelajaran Aktif Tipe Card Sort dengan Motivasi Belajar terhadap Hasil Keterampilan Bersastra ke SD-an}

Pengujian hipotesis keempat menunjukkan bahwa tidak terdapat interaksi antara model pembelajaran dengan motivasi belajar terhadap Keterampilan Bersastra ke SD-an mahasiswa. Hal ini berarti, masing-masing faktor (model pembelajaran dan motivasi belajar) tidak saling ketergantungan dan tidak saling mempengaruhi, yang menunjukkan kedua hal tersebut (model pembelajaran dan motivasi belajar) mempunyai posisi sendiri terhadap Keterampilan Bersastra ke SD-an mahasiswa.

Melalui model pembelajaran aktif tipe card sort, mahasiswa dapat memahami materi melalui pengalaman langsung yang menghubungkan antar konsep dengan permasalahan nyata dalam kehidupan sehari-hari. Melalui proses pemecahan masalah mahasiswa menggunakan kemampuan berpikir dan menerapkan konsep-konsep yang telah diperoleh untuk menyelesaikan masalah tersebut. Proses ini dapat meningkatkan pemahaman mahasiswa terhadap materi pelajaran sehingga mampu mencapai hasil belajar yang optimal. Selain itu, model pembelajaran aktif tipe card sort merupakan model pembelajaran aktivitas kerja sama yang diajakan untuk menggunakan konsep, karakteristik, klasifikasi, fakta tentang benda atau menilai informasi.

Mengingat bahwa mahasiswa memiliki gaya belajar yang berbeda, model pembelajaran aktif tipe card sort memberikan kesempatan kepada mahasiswa untuk menggali konten (materi) dengan menggunakan berbagai cara yang bermakna bagi dirinya dengan melakukan eksperimen secara kolaboratif (The George Lucas Educational Foundation, 2005). Hal ini menyebabkan mahasiswa belajar penuh kesungguhan sehingga memungkinkan setiap mahasiswa pada akhirnya mampu menjawab permasalahan yang diberikan dosen.

Dalam pembelajaran model pembelajaran aktif tipe card sort, mahasiswa dituntut untuk belajar melalui proses inkuiri, memecahkan masalah, dan merancang penyelesaian secara kolaboratif dengan adanya kelompok. Selain itu, ada beberapa faktor yang mempengaruhi motivasi belajar mahasiswa seperti mastery experiences (pengalaman menyelesaikan masalah) dan vicarious experiences (pengalaman yang diperoleh dari orang lain).

Pengalaman menyelesaikan masalah adalah sumber yang paling penting mempengaruhi motivasi belajar seseorang 
karena mastery experiences memberikan bukti yang paling akurat dari tindakan yang diambil untuk meraih suatu keberhasilan atau kesuksesan, keberhasilan tersebut dibangun dari kepercayaan yang kuat di dalam keyakinan individu. Menurut Thomas (Shamadi) bahwa pembelajaran aktif merupakan proses belajar dimana peserta didik mendapat kesempatan untuk lebih banyak melakukan aktivitas belajar, berupa hubungan interaktif dengan materi pelajaran sehingga terdorong untuk menyimpulkan pemahaman daripada hanya sekedar pembelajaran yang diberikan. Pembelajaran model pembelajaran aktif tipe card sort memberikan ruang bagi mahasiswa untuk aktif dan menyenangkan sehingga motivasi belajar akan berkembang selama proses pembelajaran.

Pada saat menjawab pertanyaan, setiap mahasiswa dalam kelompok memiliki kemampuan yang bervariasi sehingga setiap mahasiswa mencoba menunjukkan kemampuan yang mereka miliki dalam kerja tim mereka. Pada pembelajaran, mahasiswa membangun pengalamannya sendiri melalui penyelidikan sehingga mahasiswa yakin dirinya bisa menjawab pertanyaan sesuai dengan materi pelajaran. Dengan melihat temannya yang sukses menyelesaikan tugas yang diberikan, mahasiswa juga akan merasa yakin bahwa ia dapat berhasil mengerjakan tugas yang sama temannya.

Dalam proses pembelajaran, ada beberapa mahasiswa yang terlalu bergantung dengan teman kelompoknya untuk mengerjakan tugas yang diberikan dan ada juga mahasiswa yang tidak mau memberikan masukan atau tidak berperan serta mengerjakan tugas yang diberikan. Hal ini menunjukkan bahwa motivasi belajar yang dimiliki mahasiswa tidak berkontribusi untuk membuat mahasiswa mengerahkan semua kemampuan dan interaksinya dalam diskusi untuk memecahkan permasalahan yang diberikan pada pembelajaran model pembelajaran aktif tipe card sort.
Berdasarkan uraian tersebut, dapat dikatakan bahwa pengungkapan ide-ide mahasiswa itu membutuhkan kemampuan komunikasi yang efektif, kerja keras, dan rasa percaya diri yang tinggi sehingga model pembelajaran bisa berjalan dengan baik guna meningkatkan Keterampilan Bersastra ke SD-an mahasiswa.

\section{SIMPULAN}

Berdasarkan hasil penelitian yang peneliti laksanakan di Prodi PGSD FKIP Universitas Bung Hatta Padang semester genap tahun pelajaran 2015/2016, diperoleh beberapa simpulan yang merupakan jawaban atas pertanyaan-pertanyaan yang diajukan dalam rumusan masalah. Selain itu, dalam simpulan ini diungkapkan pula beberapa hasil yang ditemukan dalam penelitian. Pertama, Hasil belajar keterampilan bersastra ke SD-an mahasiswa yang diajar menggunakan model pembelajaran aktif tipe card sort lebih tinggi dibandingkan dengan hasil belajar keterampilan bersastra ke SD-an mahasiswa yang diajar menggunakan pembelajaran konvensional. Kedua, Hasil belajar keterampilan bersastra ke SD-an mahasiswa yang mempunyai motivasi belajar tinggi yang diajar menggunakan model pembelajaran aktif tipe card sort lebih tinggi dibandingkan dengan hasil belajar keterampilan bersastra ke SD-an mahasiswa yang diajar menggunakan pembelajaran konvensional. Ketiga, Hasil belajar keterampilan bersastra ke SD-an mahasiswa yang mempunyai motivasi belajar rendah yang diajar menggunakan model pembelajaran aktif tipe card sort lebih tinggi dibandingkan dengan hasil belajar keterampilan bersastra ke SD-an mahasiswa yang diajar menggunakan pembelajaran konvensional. Keempat, Tidak terdapat interaksi antara metode pembelajaran aktif tipe card sort dengan motivasi belajar terhadap hasil belajar keterampilan bersastra ke SD-an mahasiswa. 
DAFTAR PUSTAKA

Arikunto, Suharsimi. 2012. Prosedur Penelitian Suatu Pendekatan Praktek. Jakarta: Rineka Cipta.

Emzir. 2009. Metodologi Penelitian Pendidikan: Kuantitatif dan Kualitatif. Jakarta: PT Raja Grafindo Persada.

Riduan dan Sunarto. 2012. Pengantar Statistik untuk Penelitian. Bandung: Alfabeta.

Riyanto. 2010. Strategi dalam Pembelajaran. Bandung: Refika Aditama.

Sagala, Syaiful. 2010. Konsep dan Makna Pembelajaran. Bandung: Alfabeta.

Sardiman. 2006. Interaksi dan Motivasi Belajar Mengajar. Jakarta: PT RajaGrafindo Persada.

Silberman, Mel. 2009. 101 Strategi Pembelajaran Aktif. Yogyakarta: Insan Madani.

Syarifuddin, Amir. 2003. Garis-garis Besar Keterampilan Bersastra ke SD-an. Jakarta: Kencana.

Uno, Hamzah B. 2012. Teori Motivasi dan Pengukurannya. Jakarta: PT. Bumi Aksara. 